\title{
Katılımcı İklim Algısı ile Örgütsel Muhalefet Arasındaki İlişkinin
} İncelenmesi*

\author{
Examining the Relationship Between Participative Climate Perception and \\ Organizational Dissent
}

\author{
Dr. Öğr. Üyesi Serol KARALAR ${ }^{(D)}{ }^{1}$, Dr. Öğr. Üyesi Iş1 USTA KARA (iD)2
}

\begin{abstract}
$\ddot{O} z$
Siyaset bilimi kapsamında gelişen muhalefet kavramı, son yıllarda yönetim ve işletme alanında çalışan araştırmacılar tarafından da ele alınan konulardan biri haline gelmiştir. Örgüt içerisinde çalışanlara yönelik olumsuz davranışlar, eşit olmayan yönetim uygulamaları, çatışma ortamı ve örgütsel bağl1lık düzeyi çalışanların muhalif tutum ve davranışlar sergilemelerine neden olan faktörler arasındadır. Yöneticilerin eşit, şeffaf ve katılımcı bir iklim meydana getirdikleri örgütler eleştiriye ve muhalefete açık bir iş ortamı oluşturabilmektedir. Diğer taraftan örgütsel muhalefetin olasılığı durumunda çalışanların seslerini yükseltmeleri ve karar alma süreçlerine katılımları daha mümkün hale gelebilmektedir. Dolayısı ile katılımcı iklim ve örgütsel muhalefet, birbirlerini karşılıklı olarak etkileyen iki kavram olarak ortaya çıkmaktadır. Bu bağlamda araştırmanın amacı, katılımcı iklim algısı ile örgütsel muhalefet arasındaki iki yönlü ilişkiyi incelemektir. Araştırma kapsamında Huang, Van de Vliert ve Van der Vegt (2005) tarafından geliştirilen katılımcı iklim algısı ölçeği ile Kassing (1998)'in geliştirdiği ve Dağlı (2015) tarafından Türkçe’ye öğretmenlere yönelik olarak çevrilen örgütsel muhalefet ölçeği kullanılmıştır. Araştırmada Tekirdağ merkez ilçedeki devlet ilköğretim okulları ve liselerinde görev yapan 188 öğretmen üzerinde bir anket çalışması yürütülmüştür. Araştırma sonucunda elde edilen verilerin analizinde betimsel istatistikler, açıklayıcı faktör analizi ve yapısal eşitlik modellemesi kullanılmıştır. Modellerin sınanması sonucunda, katılımcı iklim algısı ile dikey muhalefet arasında karşılıklı bir ilişkinin varlığı ortaya koyulmuş olup yatay muhalefet ile katılımcı iklim algısı arasında hiçbir ilişkiye rastlanmamıştır.
\end{abstract}

Anahtar Kelimeler: Katılımcı iklim algısı, örgütsel muhalefet, yatay muhalefet, dikey muhalefet

Makale Türü: Araştırma

\begin{abstract}
Emerging in the context of political science, the notion of dissent has become one of the research topics for researchers in management and business area in recent years. Negative behaviors against employees, unequal managerial implementations, conflict and level of organizational commitment are among the factors which cause the employees to display dissident attitudes and behaviors in the organization. Organizations in which managers form equal, transparent and participative climate, can constitute a work environment open to criticism and dissent. On the other hand, employees may be more likely to raise their voices and participate in decision making processes when organizational dissent is possible. Consequently, participative climate and organizational dissent appear as two notions affecting each other. In this context, the purpose of this study is to examine the two-way relationship between participative climate perception and organizational dissent. Participative climate perception scale developed by Huang, Van de Vliert and Van der Vegt (2005) and organizational dissent scale developed by Kassing (1998) and translated into Turkish by Dağlı (2015) for teachers were used within the scope of the research. A survey was conducted on 188 teachers working in state primary and high schools in Tekirdağ city centre. Descriptive statistics,

\footnotetext{
* Bu çalışma, 15. Ulusal İşletmecilik Kongresi'nde bildiri olarak sunulmuş olup yazın kısmına yeni kaynaklar eklenmiş ve veriler başka bir analiz tekniği ile tekrar değerlendirilmiştir.

${ }^{1}$ Trakya Üniversitesi Sağlık Bilimleri Fakültesi, serolkaralar@trakya.edu.tr.

${ }^{2}$ Trakya Üniversitesi Sağlık Bilimleri Fakültesi, isilusta@trakya.edu.tr.
}

Atıf için (to cite): Karalar, S. ve Usta Kara, I. (2020). Katılımcı iklim algısı ile örgütsel muhalefet arasındaki ilişkinin incelenmesi. Afyon Kocatepe Üniversitesi Sosyal Bilimler Dergisi, 22(3), 714-729. 
explanatory factor analysis and structural equation modelling were used in the analysis of the data obtained from the research. As a result of testing the models, it was revealed that there was a bilateral relationship between participative climate perception and vertical dissent while any relationships were encountered between horizontal dissent and participative climate perception.

Keywords: Participative climate perception, organizational dissent, horizontal dissent, vertical dissent

Paper Type: Research

\section{Giriş}

Yaşanan küresel rekabetin etkisi ile günden güne değişen iş yaşamında çalışan memnuniyetinin sağlanması için çeşitli yönetim uygulamaları ve kavramları geliştirilmektedir. Bu konuda önde gelen kavramlardan bir tanesi katılımcı iklimdir. Katılımcı iklimin hakim olduğu örgütlerde çalışanlar yöneticileri ile iletişim kurabilmekte, alınan kararlara katılabilmekte ve örgüt içerisinde eksik veya yanlış gördükleri hususları bildirebilmektedirler. Söz konusu ortamın gerçekleşmesi örgütsel muhalefet olarak adlandırılan bir başka kavramın ortaya çıkmasını sağlamaktadır. Çalışanların örgütlerine muhalefet etme düzeyleri yükseldikçe karar alma mekanizmalarına katılma sıklıkları da artabilmektedir. Dolayısı ile katılımcı iklim ve örgütsel muhalefetin birbirlerini etkileyen ve aralarındaki ilişkinin incelenmesi gereken kavramlar olduğu belirtilebilir.

Çalışmada, öğretmenlerin katılımcı iklim algıları ile örgütsel muhalefet davranışları arasındaki ilişkiyi incelemek amaçlanmıştır. Öncelikle, katılımcı iklim ile örgütsel muhalefet kavramlarının irdelendiği yazın taraması yapılmış olup ilgili yazında iki kavramı birlikte ele alan ve öğretmenler üzerinde gerçekleştirilmiş bir çalışmaya rastlanmamıştır. Tespit edilen bu eksikliğin giderilmesinin ve iki değişken arasındaki ilişkinin ampirik boyutunun ortaya koyulmasının ilgili yazın için önemli olduğu düşünülmektedir. Çalışmada, araştırma amacı doğrultusunda Tekirdağ merkez ilçedeki devlet ilköğretim okulları ve liselerinde görev yapan ögretmenler üzerinde uygulanan anket çalışmasının sonuçlarına yer verilmiştir.

\section{Kavramsal Çerçeve}

Bu bölümde; katılımcı iklim algısı ve örgütsel muhalefet kavramları tanımlanmış, söz konusu kavramlar ile ilgili olarak yazında araştırmacılar tarafından gerçekleştirilen çalışmalara yer verilmiş ve iki kavram arasındaki ilişkiden söz edilmiştir.

\subsection{Katılımcı İklim Kavramı}

Katılımcı iklim kavramının doğuş noktası olarak katılımcı yönetim kabul edilmektedir. Geleneksel örgütlerin kontrol temelli uygulamalarına kıyasla katılımcı yöntemler; işe devamsızlık ve işten ayrılma niyeti düzeyini azaltırken bireysel iş performansı, iş tutumları ve çalışan-örgüt ilişkisini geliştirmektedir (Tesluk, Vance \& Mathieu, 1999, s. 271). Katılımcı yönetim uygulamaları yüzyılı aşkın bir süredir var olmakla birlikte 1970'lerde örgütlerin, işleri etkileyen konularda çalışanlara söz hakkı vermeleri gerektiğini fark etmeleri ile kapsam ve uygulama açısından gelişmiştir (Angermeier, Dunford, Boss \& Boss, 2009, s. 128). Yaşanan bu gelişmenin ardından katılımcı iklim algısı, araştırmacılar tarafından incelenmesi gereken bir kavram olarak ortaya çıkmıştır.

Katılımcı iklim; yeni fikirler, öneriler ve hatta muhalif görüşlerin yönetim tarafından ne ölçüde desteklendiği ile ilgili olarak çalışanların ortak algılarını ifade etmektedir (Huang et al., 2005, s. 463). Katılımcı iklimin belirleyicileri; elde etmek için çaba gösterilen ortak örgütsel amaçlar ile ilgili çalışan algısı olarak ifade edilen kurumsal amaç bağımlılığı, örgüt amaçlarının çalışanlar üzerinde etkisinin olmaması ile ilgili çalışan algısı olarak tanımlanan özerk amaç bağımlılığı ve kararlar ile faaliyetlerin sonuçlandırılmasında yararlanılan farklı bakış açılarının 
güçlendirilmesi için işyerindeki uyuşmazlıkların olumlu açıdan değerlendirilmesi olarak belirtilen yapıcı uyuşmazlık olmak üzere üç unsurdan oluşmaktadır (Turnbull, 1999, s. 132).

Katılımcı iklimin belirlenmesinde, üst yönetimin katılıma ilişkin tutum ve davranışları önemli bir rol oynamaktadır (Tesluk et al., 1999, s. 275). Katılımcı iklimi tutum ve davranışları ile oluşturan yöneticiler aynı zamanda, meydana getirecekleri katılımcı iklim türü ile ilgili bir seçim yapma olanağına da sahiptirler. Katılımcı iklim türlerinden ilki olan bilgi paylaşımı iklimi, iş ile ilgili konularda çalışanlara fikirlerini söyleme cesareti veren yönetim uygulamalarını içermektedir. Diğer katılımcı iklim türü olan karar alma iklimi ise çalışanlara, işlerini uygun gördükleri gibi organize etme ve gerçekleştirme sorumluluğu ve özgürlüğü vermektedir (Brown \& Cregan, 2008, s. 670). Katılımcı iklime sahip örgütlerde bilgi, yaratıcılık ve çalışanların özgürlügüne değer verilmekte ve bireysel katkı ile kişisel inisiyatife vurgu yapılmaktadır (Bordin, Bartram \& Casimir, 2007, s. 37). Diğer taraftan katılımcı iklim, çalışanların iş arkadaşları ve yöneticileri ile olan sosyal etkileşimlerinden etkilenmektedir (Huang et al., 2005, s. 464). Buradan hareketle, yöneticilerin ve çalışanların etkisi ile örgüt içerisinde benimsenen katılımcı iklimde bilgi paylaşımı, özgürlük, eleştiri, inisiyatif ve sosyal ilişkilerin önemli olduğu belirtilebilir.

Örgüt içerisindeki katılımcı iklimin çalışan tutumları üzerinde, çalışanların sadece belirli kararlara katılımlarından daha fazla etkili olduğu belirlenmiştir (Bartkus, 1997, s. 338). Örneğin; yalnızca amaçların belirlenmesine katılım, verimlilik üzerinde güçlü bir etki yaratmamaktadır (Miller \& Monge, 1986, s. 748). Bu nedenle, katılımcı iklim algısının örgüt geneline yayılmas1 gerekmektedir. Ayrıca katılımcı iklimin yönetim tarafından kısa dönemli ve/veya davranışsal kapsamından çıkartılarak, örgütün farklı seviyelerinde doğal iş grupları ve kendi kendini yöneten takımların kullanılması ile birlikte daha stratejik açıdan ele alınması gerekli görülmektedir (Liverpool, 1990, s. 421). Dolayısı ile, çalışanlara bazı kararların alınmasında söz verilmesi yerine genel olarak katılımcı iklim algısının oluşturulmasının ve katılımcı iklimin uzun dönemli olarak düşünülmesinin önem taşıdığı söylenebilir.

İlgili yazında katılımcı iklim kavramı, araştırmacılar tarafından birçok kavram ile ilişkilendirilmiş̧ir. Bu kavramlar arasında karar alma (Liverpool, 1990; Taylor \& Tashakkori, 1994; Tesluk et al., 1999; Turnbull, 1999), kalite çemberleri (Liverpool, 1990), örgütsel ses, sessizlik ve güç mesafesi (Huang et al., 2005; Demiralay, 2014; Lee, Diefendorff, Kim \& Bian, 2014), personel güçlendirme (Short \& Rinehart, 1992; Bordin et al., 2007), yenilikçi davranış ve proaktif kişilik (Bal Taştan, 2013), örgütsel sinizm (Brown \& Cregan, 2008), tükenmişlik ve işten ayrılma niyeti (Angermeier et al., 2009), kişilik (Lee et al., 2014), işgören elde tutma ve rol performansı (Jadon \& Upadhyay, 2018) yer almaktadır. Kavramsal çerçevenin ikinci bölümünde, araştırmanın bir diğer değişkeni olan ve çalışanların katılımcı iklim algılarını etkileyen örgütsel muhalefet kavramını tanımlamanın önem taşıdığı düşünülmektedir.

\section{2. Örgütsel Muhalefet Kavramı}

Muhalefet, "Bir tutuma, bir görüşe, bir davranışa karşı olma durumu, aykırılık" olarak ifade edilmektedir (tdk.gov.tr, 09.02.2019). Kelimenin İngilizce karş1lı̆̆ olan "dissent" ise Latince kökenli olup "ayr1, farklı hissetmek" anlamına gelmektedir (Kassing, 1997, s. 312). Diğer bir tanım ile muhalefet, ortak veya resmi olarak kabul edilen fikirlerle çelişen görüş ve düşüncelere sahip olmak veya bunları dile getirmektir (www.oxforddictionaries, 09.02.2019). Muhalefet, siyaset bilimi çerçevesinde gelişen bir kavram olmakla birlikte son y1llarda örgüt ve yönetim yazınında da irdelenen konulardan biri haline gelmiştir (Özdemir, 2011, s. 1896). Bu sayede örgütsel muhalefet kavramı ortaya çıkmıştır.

Temel olarak örgütsel muhalefet; örgütsel politikalar ve uygulamalara karş1 anlaşmazlıkların veya karşııt görüş ve fikirlerin ifade edilmesi olarak tanımlanmaktadır (Kassing, 1997, s. 312). Başka bir tanım ile örgütsel muhalefet; mevcut örgüt politikaları ve uygulamalarını sorgulayan çalışan geribeslemesidir (Garner, 2011, s. 3). Ayrıca örgütsel muhalefet bir işgören duruşu ve tavrı olup açık bir protestoyu veya pozitif yarar duygusuyla itirazı tanımlamaktadır (Sadykova ve Tutar, 2014, s. 3). Nitekim örgütsel muhalefet, örgütün problem çözme ve karar 
alma becerilerini geliştirmekte ve çalışan performansı ile iş tatminini artırmaktadır (Garner, 2013, s. 2). Buradan hareketle, genel olarak olumsuz bir imaja sahip olan örgütsel muhalefetin örgüt açısından olumlu yanlarının da bulunduğu söylenebilir.

Örgüt içerisinde çalışanların muhalif davranışları çeşitli etkenler tarafından tetiklenmektedir. Örgütsel muhalefet genel olarak örgütsel, ilişkisel ve bireysel nedenlerle oluşmaktadır (Kassing \& Avtgis, 1999, s. 100). Kaynakların yetersizliği, performans değerlendirmeleri, örgütsel verim düşüklüğü, katılım olanağının olmaması, örgütsel değişim, etik kaygılar, örgütsel çatışmanın önlenmek istenmesi, örgütsel özdeşleşme, sorumluluk alma, çalışanlara karşı olan olumsuz tutum ve davranışlar örgütsel muhalefete neden olan unsurların başında gelmektedir (Kassing, 1997, s. 314; Mehta, 2009, s. 194; Turnage \& Goodboy, 2014, s. 3). Bahsedilen unsurlar aynı zamanda örgütsel muhalefetin analiz edilmesinde dikkate alınması gereken unsurları oluşturmaktadır.

Örgütsel muhalefet davranışı çalışanlar tarafından üç şekilde sergilenmektedir. Açık veya dikey muhalefet; hiyerarşik örgüt kanallarının ve örgütsel değişim üzerinde etkisi bulunduğu düşünülen yönetici, müdür gibi otorite unsurlarının kullanılmasını içermekte; yatay veya gizli muhalefet ise dikey muhalefet mümkün olmadığında veya istenmediğinde muhalefetin iş arkadaşlarına ifade edilmesini tanımlamaktadır (Croucher et al., 2009, s. 179). Dikey muhalefetin gerçekleşememesi durumunda çalışanlar kendilerini engellenmiş olarak algılamakta ve muhalefetlerini örgüt içerisinde etkisi olmayan kişilere ya da kendini engellenmiş hisseden çalışma arkadaşlarına daha agresif bir şekilde belirtmektedirler (Yıldız, 2013, s. 858). Son olarak; yer değiştirmiş veya dolaylı muhalefet ise anlaşmazlığın aile, arkadaşlar veya yabancı kimseler gibi dışsal unsurlara anlatılmasıdır (Croucher et al., 2009, s. 179). Bilgi uçurma (Whistleblowing) ile benzerlik gösterdiği düşünülmekle birlikte dolaylı muhalefette, bilgi uçurmanın aksine medya veya siyasi kaynaklara aktarımda bulunulmamaktadır (Kassing \& Avtgis, 1999, s. 103). Dolaylı muhalefetin amacı dikkatleri örgüte çekmek değil, çalışan gerilimini azaltmak için psikolojik boşalma görevi görmektir (Avtgis, Thomas-Maddox, Taylor \& Patterson, 2007, s. 99).

Çalışanların muhalif görüşlerini ifade etme stratejileri ve bu görüşleri ilettikleri iletişim kanalları yanlış olabilmektedir. $\mathrm{Bu}$ durum, örgüt içerisinde muhalefetin olmadığ 1 algısını yaratabilmektedir (Kassing, 1997, s. 312). Bu algı yanlışlığına düşmemek için yöneticilerin üzerine düşen görevler bulunmaktadır. Örgüt içerisinde yöneticiler, muhalif davranışlar sergileyen örgüt üyelerine tepkilerini ödüllendirme, cezalandırma ve yok sayma olmak üzere üç şekilde göstermektedirler (Dağl1, 2015, s. 199). Ancak yöneticilerin unutmamaları gereken nokta; muhalefetin örgüt içerisinde tam olarak sona ermediği, her zaman kısmen var olduğudur (Ötken ve Cenkci, 2013, s. 41). Önemli olan; yöneticilerin, örgütsel muhalefeti örgütün bir parçası olarak görmeleridir.

$\mathrm{Bu}$ araştırmanın katılımcıları olan öğretmenlerin genellikle hayata geçirilen eğitim reformlarına, aşırı bürokratik ve merkeziyetçi kontrol mekanizmalarına ve düşük ücret politikalarına karşı muhalif davranışlar gösterdikleri görülmektedir (Özdemir, 2011, s. 1897). Türkiye'de öğretmenleri muhalefet etmeye iten nedenleri ve örgütsel muhalefet davranışlarının etkilerini araştıran çalışmaların sayısı az olmakla birlikte son yıllarda bir artış gözlemlenmektedir. Yapılan araştırmalara göre öğretmenlerin en çok dikey muhalefet davranışı sergilediği tespit edilmiştir.

Özdemir (2013)'in Ankara'daki 134 lisede gerçekleştirmiş olduğu araştırmada öğretmenlerin en sık olarak, yöneticinin kendisine itiraz ederek dikey muhalefet davranış1 sergilemeyi tercih ettikleri belirlenmiştir. Akada ve Beycioğlu (2017) tarafından İzmir ili Buca merkez ilçesindeki kamu ortaokullarında görevli öğretmenler ile yapılan çalışmada katılımcı öğretmenlerin, okul müdürlerine karşı çoğunlukla açık/yukarıya muhalefet davranışlarında bulundukları ortaya koyulmuştur. Uğurlu ve Bostancı (2017)'nın İzmir ilindeki ortaokullarda görev yapan öğretmenler üzerinde gerçekleştirdiği araştırmada, muhalif davranış gösterme 
durumları orta düzeyde olan katılımcıların en çok dikey muhalefet davranışını sergiledikleri tespit edilmiştir.

Iliman Püsküllüoğlu ve Altınkurt (2018) tarafından Muğla ilinde görevli öğretmenler üzerinde yürütülen çalışmada katılımcıların örgütsel muhalefet davranışlarının orta düzeyde olduğu ve bu davranışlarını en çok yöneticilerine ifade ettikleri saptanmıştır. Eskişehir ilinde görev yapan temel eğitim ve ortaöğretim kurumlarında yapılan çalışmada öğretmenlerin dikey muhalefet davranışında bulunduklarını desteklemektedir (Korucuoğlu ve Şentürk, 2018). Acaray (2018)'ın İstanbul'daki özel eğitim kurumlarında görev yapan öğretmenler üzerinde gerçekleştirdiği araştırmada da en çok tercih edilen örgütsel muhalefet türünün diket muhalefet olduğu belirlenmiştir.

İlgili yazın incelendiğinde; örgütsel muhalefet kavramının iletişim (Kassing \& Avtgis, 1999; Garner, 2011), örgütsel özdeşleşme (Kassing, 2000a), tükenmişlik (Avtgis et al., 2007), örgütsel adalet (Goodboy, Chory \& Dunleavy, 2008), tartışmacılık (Croucher et al., 2009), kişilik (Ötken ve Cenkci, 2013), örgütsel bağlılık (Yıldız, 2013), örgütsel ses (Garner, 2013), örgütsel sinizm (Yıldız, 2013), örgütsel demokrasi (Sadykova ve Tutar, 2014; Oral Ataç ve Köse, 2017), lider-üye etkileşimi (Kassing, 2000b; Turnage \& Goodboy, 2014), okul kültürü ve mesleki değerler (Kadı ve Beytekin, 2015), işyerinde konuşma özgürlüğü (Croucher, Zeng, Rahmani \& Cui, 2017), politik yeti (Uğurlu ve Bostanc1, 2017), mesleki öz yeterlilik (Bakan, Doğan ve Yılmaz, 2017), eleştirel düşünme eğilimi (Iliman Püsküllüoğlu ve Altınkurt, 2018) ve pozitif psikolojik sermaye (Acaray, 2018) kavramları ile ilişkilendirildiği çalışmalara rastlanmıştır.

\subsection{Katılımcı İklim ile Örgütsel Muhalefet Arasındaki İlişki}

Katılımcı iklim, özellikle otoriter yönetim tarzından kaynaklanan düşük moral, motivasyon ve örgütsel verimlilik düzeyi gibi sorunların çözülmesi için kullanılabilecek bir seçenek olarak kabul görmektedir (Bal Taştan, 2013, s. 410). Ayrıca katılımcı iklimin olduğu bir ortamda çalışmanın, çalışanların iş tatmini düzeylerini artırdığı bilinmektedir (Miller \& Monge, 1986, s. 745). Bu doğrultuda katılımcı iklimin, örgütlere önemli avantajlar sağladığı belirtilebilir.

İşyerinde eleştirel ortamın olumlu yönde olması ile ilgili çalışan algısı olarak tanımlanan katılımcı iklim; çalışanların alınan kararlara etki ve katılım düzeyi ile şekil bulmaktadır (Smits \& Champagne, 2008, s. 429). Karar alma ve geribesleme süreçlerine aktif bir şekilde dahil edilen, serbest ve katılımcı bir iklimde görev yapan çalışanlar düşüncelerini açık ve çekinmeden ifade edebilmektedirler (Huang et al., 2005, s. 460). Diğer bir deyişle katılımcı iklim, çalışanların örgütsel ses davranışlarını olumlu yönde etkilemektedir (Lee et al., 2014, s. 28). Örgüt içerisinde seslerini duyurabilen çalışanların, yönetime karşı olan eleştirilerini söyleme ve muhalefet etme olanakları doğabilmektedir. Dolayısı ile örgüt içerisinde eleştirel ve muhalif düşüncelerin dile getirilmesine ortam oluşturan katılımcı iklimin, örgütsel muhalefet kavramını geliştirici bir etkisinin olduğu söylenebilir.

Çalışanlar muhalefet etme niyetinde olduklarında örgüt kültürü ve iklimini göz önünde bulundurmaktadırlar. Çalışma ortamında konuşma özgürlüğü ve açıklık gibi örgütsel niteliklerin yanı sıra örgütün muhalefete daha önceden vermiş olduğu tepkiler katılımcı iklimin oluşmasına katkı sağlamaktadır (Croucher et al., 2009, s. 179). Örgütsel muhalefet, demokratik örgütler kadar geleneksel örgütlerde de çalışan katılımının bir göstergesi olarak görülmektedir (Kassing, 1998, s. 187). Bu doğrultuda, katılımcı iklim ve örgütsel muhalefet birbirlerini karş1lıklı etkileyen iki kavram olarak ele alınabilir.

Örgüt içerisinde çalışanların fikir ve görüşlerini ifade edebilmeleri ve alınan kararlara dahil edilmeleri örgütler ve çalı̧̧anlar açısından olumlu sonuçlar doğurmaktadır. Bu sayede çalışanların güven duyguları ve motivasyon düzeyleri yükselebilmekte, bireysel ve örgütsel performansları artabilmektedir. Örgüt içerisinde eleştirel bir ortama ve muhalif görüşlere olanak sağlayan katılımcı iklim algısı, örgütsel muhalefetin gelişmesini kolaylaştırmaktadır. Aynı şekilde örgütsel muhalefet davranışları, katılımcı iklimin güçlenmesine yardımcı olmaktadır. 
Katılımcı iklim algısı ve örgütsel muhalefet kavramlarının, öğretmenler ve okullar açısından da önem taşıdığı düşünülmektedir. Çünkü katılımcı iklime sahip okullarda görev yapan öğretmenlerin mesleki faydaları ve iş memnuniyeti düzeyleri artmaktadır (Taylor \& Tashakkori, 1994, s. 3).

Örgütsel muhalefet kökenlerini örgütsel ses kavramından aldığı için eğitim örgütlerinde gerçekleşen etkinliklere ilişkin ortaya çıkan ses, yani örgütsel muhalefet davranışı, yanlış olan uygulamaların düzeltilmesine ve var olan uygulamaların iyileşmesine katkı sağlayabilir. Özellikle yöneticilere ifade edilen muhalefet davranışının zayıflı̆̆ 1 , okullarda korku kültürünün oluşup gelişimin yavaşlamasına neden olabilir (Iliman-Püsküllüoğlu ve Altınkurt, 2018, s. 901). Bu nedenle öğretmenlerin sesini çıkarabileceği katılımcı bir iklimin hakim olduğu bir çalışma ortamının varlığı önemli görülebilir.

\section{Yöntem}

Bu bölümde; araştırmanın evreni ve örneklemi, kullanılan veri toplama araçları, araştırma modeli ve hipotezleri ile araştırmanın sınırlılıklarına yer verilmiştir.

\subsection{Araştırmanın Evreni ve Örneklemi}

Katılımc1 iklim algısı ile örgütsel muhalefet arasındaki iki yönlü ilişkinin ortaya koyulması amacıyla yürütülen araştırmanın evreni, Tekirdağ merkez ilçedeki devlet ilköğretim okulları ve liselerinde görev yapan öğretmenlerden meydana gelmektedir. Milli Eğitim Bakanlığı'nın web sitesinde yer alan okul bilgilerine göre Tekirdağ merkez ilçedeki okullarda 371 öğretmen bulunmakta olup araştırmanın evrenini oluşturmaktadır. Araştırmada nicel analiz yöntemi tercih edilmiş olup basit tesadüfi olmayan örneklem yöntemlerinden olan kolayda örnekleme yöntemi kullanılmıştır. Araştırmaya katılan 188 katılımcı araştırmanın örneklemini oluşturmaktadır. Belirlenen araştırma evreninden oluşan örneklem büyüklügünün, araştırmacılar tarafından genel olarak kabul edilen $\% 95$ güvenilirlik düzeyinde $n=183(\mathrm{~N}=350)$ ile $\mathrm{n}=196$ $(\mathrm{N}=400)$ arasında olması uygun bulunmaktadır (Cohen, Manion \& Morrison, 2007, s. 104). Buradan hareketle, araştırmanın örneklem büyüklüğünün yeterli olduğu belirtilebilir.

\subsection{Araştırmada Kullanılan Veri Toplama Araçları}

Araştırmada veri toplama aracı olarak yüz yüze anket tekniğinden yararlanılmıştır. Araştırmada kullanılan anket üç bölümden meydana gelmektedir. Anketin birinci ve ikinci bölümünde katılımcı iklim algısı ve örgütsel muhalefet ile ilgili olarak önceden geliştirilmiş, geçerliliği ve güvenilirliği sınanmış ölçekler kullanılmıştır. Ölçekleri oluşturan ifadelerin tümü 5'li Likert tipi ( $1=$ Kesinlikle katılmıyorum. $.5=$ Kesinlikle kat1liyorum) sorulardır.

Araştırma kapsamında uygulanan katılımcı iklim algısı ölçeği Huang, Van de Vliert \& Van der Vegt (2005) tarafından geliştirilmiş olup 4 ifade ve tek boyuttan oluşmaktadır. Söz konusu ölçeğin Cronbach alfa katsayısı araştırmacılar tarafından $\alpha=0,72$ olarak belirlenmiştir.

Kassing (1998)'in geliştirdiği ve Dağlı (2015) tarafından Türkçe'ye öğretmenlere yönelik olarak çevrilen örgütsel muhalefet ölçeğinde ise 15 ifade ve 2 alt boyut bulunmaktadır. Örgütsel muhalefet ölçeğinde yer alan dikey muhalefet; çalışanların aykırı görüşlerini, zıt fikirlerini ve anlaşmazlıklarını örgütte aktif olarak hareket edebilecek yöneticilere yapıcı biçimde ifade etmeleri şeklinde tanımlanırken yatay muhalefet ise çalışanların sorun olarak değerlendirdikleri durumları örgütsel süreçlerde güce sahip olanlar yerine sorunun çözümüne etki etmeyecek etkisiz tarafa eleştirel ve saldırgan biçimde dile getirmeleri olarak ifade edilmektedir (Acaray, 2018, s. 85). Kassing (1998) tarafından gerçekleştirilen ölçek geliştirme çalışmalarında ölçeğin alt boyutlarının Cronbach alfa katsayısının $\alpha=0,66$ ile $\alpha=0,88$ arasında değiştiği görülmektedir. Dağlı (2015)'nın çalışmaları sonucunda öğretmenler üzerinde uygulanan ve Türkçeleştirilen ölçeğin Cronbach alfa katsayısı $\alpha=0,85$ olarak saptanmıştır.

Araştırmanın üçüncü bölümünde ise, katılımcıların sosyo-demografik özelliklerini belirlemeye yönelik hazırlanan 8 adet soru yer almaktadır. 


\subsection{Araștırma Modeli}

Araştırma kapsamında irdelenen değişkenler arasındaki ilişkiyi sınayabilmek için bir araştırma modeli geliştirilmiştir. Araştırma modeline Şekil l'de yer verilmiştir.

\section{Şekil 1. Araştırma modeli}

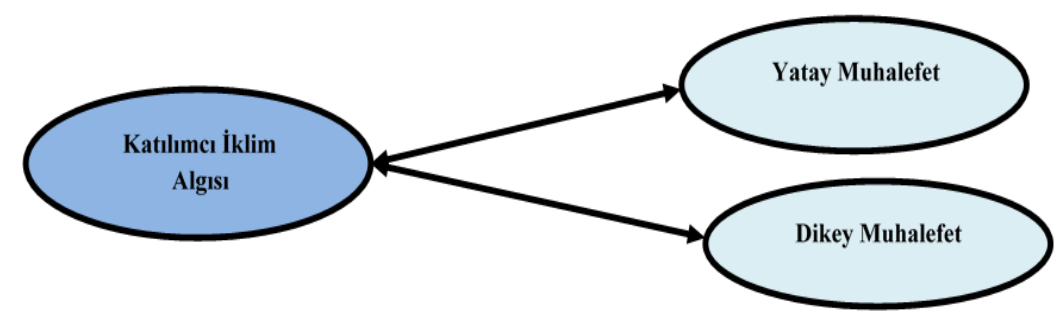

Şekil 1'de görüldüğü gibi; araştırma kapsamında ilk olarak katılımcı iklim algısının, örgütsel muhalefetin alt boyutları olan dikey ve yatay muhalefet üzerindeki etkisi incelenmektedir. Ardından, dikey ve yatay muhalefetin katılımcı iklim algısı ile olan ilişkisi irdelenmektedir. Oluşturulan model doğrultusunda, araştırmada test edilmek istenen hipotezler ortaya koyulmuştur.

\subsection{Araştırmanın Hipotezleri}

Araştırma modeli kapsamında test edilmek istenen araştırma hipotezleri Tablo 1'de gösterilmiştir.

Tablo 1. Araştırmanın hipotezleri

$\mathrm{H}_{1}$ : Katılımcı iklim algısının, dikey muhalefet üzerinde anlamlı bir etkisi vardır.

$\mathrm{H}_{2}$ : Katılımc iklim algısının, yatay muhalefet üzerinde anlamlı bir etkisi vardır.

$\mathrm{H}_{3}$ : Dikey muhalefetin, katılımcı iklim algısı üzerinde anlamlı bir etkisi vardır

$\mathrm{H}_{4}$ : Yatay muhalefetin, katılımcı iklim algısı üzerinde anlamlı bir etkisi vardır.

\subsection{Verilerin Analizi}

Tekirdağ merkez ilçedeki devlet ilköğretim okulları ve liselerinde görev yapan öğretmenler üzerinde uygulanan anketten elde edilen veriler SPSS 17.0 ve AMOS 23 paket programları kullanılarak değerlendirilmiş ve ortaya çıkan sonuçlar yorumlanmıştır. Öncelikle araştırma katılımcılarının sosyo-demografik özelliklerini belirlemek amacı ile tanımlayıcı istatistiklere bakılmıştır. Anketlerden elde edilen veriler açıklayıcı faktör analizine (AFA) tabi tutulmuştur. Araştırmada kullanılan veri setinin faktör analizine uygun olup olmadığını belirlemek için Kaiser-Meyer-Olkin (KMO) testi ve Bartlett testi sonuçlarına bakılarak veri setinin faktör analizi için oldukça uygun olduğu görülmüş̧ür. Faktör analizinde tek boyut oluşturan bir adet ifade analizden çıkarılmıştır. AFA ile çalışmada katılımcı iklim, dikey ve yatay muhalefet olmak üzere 3 boyut belirlenmiştir. Boyutların Cronbach Alfa $(\alpha)$ katsayıları hesaplanmış olup güvenilirlik düzeylerinin yüksek olduğu söylenebilir.

Boyutlar arasındaki etkileşimi tanımlamak üzere bağımsız iki teorik model geliştirilmiştir. İlk modelde örgütsel muhalefetin alt boyutları bağımsız, katılımcı iklim bağımlı değişken olarak belirlenmiştir. İkinci modelde ise katılımcı iklim bağımsız, yatay ve dikey muhalefet alt boyutları bağımlı değişkenler olarak yer almıştır. İlgili modelleri test etmek amacıyla yapısal eşitlik modellemesi (YEM) tercih edilmiştir. YEM tekniğinin uygulanabilmesi için belirli varsayımların gerçekleştirilmesi gerekmektedir. Örneklem büyüklüğünün uygun olması, gözlenen ve gizil değişkenlerin çok değişkenli normal dağılıma sahip olması, doğrusallık, çoklu doğrusal bağlantının ve aykırı değerlerin olmaması YEM'in varsayımlarıdır. Örneklem büyüklüğü konusunda ilgili yazında farklı görüşler bulunmakla birlikte genellikle 100 'den az örneklem küçük, 100-200 arası örneklem hacmi orta ve 200'den fazla örneklem hacmi ise büyük 
örneklem olarak tanımlanmaktadır (Bayram, 2010, s. 51). Bu doğrultuda araştırmanın 188 olan örneklem büyüklüğ̈nün yeterli olacağı görülmektedir.

Verilerin çok değişkenli normalliğini değerlendirmek için kullanılan yöntemlerden biri Mardia'nın çok değişkenli çarpıklık ve basıklık katsayılarıdır (Kline, 2011, s. 54; Bryne, 2010; Mardia, 1970). Çalışmada çok değişkenli normallik varsayımı için Mardia basıklık katsayısı kullanılmıştır. Analiz sonucuna göre kurtosis değeri 61,423 ve kritik oran (c.r.) 15,011>1,96 olarak belirlenmiş ve veri setinin çok değişkenli normallik varsayımını sağlamadığı anlaşılmıştır. $\mathrm{Bu}$ nedenle çalışmada bootsrap maksimum olabilirlik yöntemi kullanılmıştır.

Değişkenler arasındaki ilişkileri tespit etmek amacıyla iki yapısal eşitlik modeli oluşturulmuştur. Öncelikle ilgili modeller varsayımlar açısından sınanmıştır.

Her iki model için veri setinde aykırı ve uç değerlerin saptanabilmesi için Mahalanobis uzaklıkları kullanılmış, aykırı ve uç değer tespit edilmediği için hiçbir gözlem analiz dışı bırakılmamıştır. Doğrusallık varsayımının test edilmesi amacıyla Pearson Korelasyon Katsayısı irdelenmiş ve ulaşılan anlamlı katsayılar ile doğrusallık varsayımının sağlandığı sonucuna ulaşılmıştır.

YEM varsayımlarından olan çoklu doğrusal bağlantının saptanabilmesi için veri seti, Varyans artış faktörleri (VIF) ile değerlendirilmiştir. VIF değerlerinin 10'nun üzerinde olmas1 ciddi bir doğrusal bağlantı olduğunu göstermektedir (Çokluk vd., 2012, s. 35). Çalışmaya ait VIF değerleri 1,066 ile 2,749 değerleri arasında yer almaktadır. Ayrıca modellerin uyum iyiliği indekslerinin analiz için yeterli olduğu görülmüştür. Yapısal eşitlik modellemesinin yapılabilmesi için gerekli olan varsayımlar sağlanarak modellerin analizi gerçekleştirilmiştir.

\subsection{Araştırmanın Sınırlılıkları}

Bilimsel araştırmaların yürütülmesi sürecinde en doğru sonuçlara ulaşılmasına engel olan birtakım sınırlılıklarla karşılaşılmaktadır. Bu araştırmanın en temel sınırlılığı, anket çalışmasının Tekirdağ merkez ilçedeki devlet okullarında gerçekleştirilmesi ve araştırma sonuçlarının sadece anketin uygulanabildiği öğretmenler tarafından verilen cevaplara göre şekillenmiş olmasıdır. Zaman kısıtı nedeniyle bu sınırlılık unsuru ortadan kaldırılamamıştır. Söz edilen temel sınırlılığın yanı sıra; anket çalışmasının araştırma evreninin tamamına uygulanamaması ve 188 öğretmenin araştırmaya katılmayı kabul etmesi araştırmanın diğer sınırlılığını oluşturmaktadır. Dolayısı ile araştırma sonuçlarını Tekirdağ merkez ilçedeki tüm öğretmenlere genelleştirme hususunda da sinırlılıklar doğmuştur.

\section{Bulgular}

Tablo 2'de, araştırmaya katılan öğretmenlerin sosyo-demografik özelliklerine göre dağılımı görülmektedir.

Tablo 2. Katılımcıların sosyo-demografik özelliklerine göre dağılımı

\begin{tabular}{|c|c|c|c|c|c|}
\hline $\begin{array}{c}\text { Sosyo-Demografik } \\
\text { Özellik }\end{array}$ & Frekans & Yüzde & Sosyo-Demografik Özellik & Frekans & Yüzde \\
\hline Cinsiyet & & & Çalışılan Kurum & & \\
\hline Kadin & 104 & 55,3 & İlköğretim & 101 & 53,7 \\
\hline Erkek & 84 & 44,7 & Lise & 87 & 46,3 \\
\hline Toplam & 188 & 100,0 & Toplam & 188 & 100,0 \\
\hline Yaş & & & Kurumda Calısma Süresi & & \\
\hline $22-32$ yaş & 46 & 24,5 & $1-10 \mathrm{y} 11$ & 141 & 75,0 \\
\hline $33-43$ yaş & 69 & 36,7 & $11-20$ y1l & 31 & 16,5 \\
\hline 44-54 yaş & 58 & 30,9 & 21-30 yil & 16 & 8,5 \\
\hline 55 yaş ve üzeri & $\begin{array}{l}15 \\
188\end{array}$ & 8,0 & Toplam & 188 & 100,0 \\
\hline
\end{tabular}




\begin{tabular}{|c|c|c|c|c|c|}
\hline \multirow{5}{*}{$\begin{array}{c}\text { Medeni Durum } \\
\text { Bekar } \\
\text { Evli } \\
\text { Toplam }\end{array}$} & \multicolumn{5}{|c|}{ Toplam Çalışma Süresi } \\
\hline & & & $1-10$ y1l & 51 & 27,1 \\
\hline & 43 & 22,9 & $11-20 \mathrm{v} 1 \mathrm{l}$ & 79 & 42,0 \\
\hline & 145 & 77,1 & $\begin{array}{ll}11-20 \\
21-30 \\
2\end{array}$ & 58 & 30,0 \\
\hline & 188 & 100,0 & Toplam & $\begin{array}{c}58 \\
188\end{array}$ & $\begin{array}{r}50,9 \\
100,0\end{array}$ \\
\hline & \multicolumn{5}{|c|}{ Kurumda Bir Yakının } \\
\hline Eğitim Durumu & & & Çalıșma Dur & & \\
\hline Lisans & 154 & 81,9 & Evet & 26 & 13,8 \\
\hline Yüksek Lisans & 34 & 18,1 & Hayır & 162 & $86 ?$ \\
\hline Toplam & 188 & 100,0 & $\begin{array}{l}\text { Hayır } \\
\text { Toplam }\end{array}$ & $\begin{array}{l}102 \\
188\end{array}$ & $\begin{array}{c}00,2 \\
100,0\end{array}$ \\
\hline
\end{tabular}

Tablo 2'ye göre; araştırma kapsamındaki öğretmenlerin çoğunluğu kadın, 33-43 yaş aralığında, evli, lisans mezunu, ilköğretim okullarında görev yapan, bulundukları kurumda 1-10 yıldır çalışan, toplam çalışma süresi 11-20 yıl olan ve aynı kurumda eş, kardeş gibi bir yakını çalışmayan katılımcılardan oluşmaktadır.

Araştırmada kullanılan veri setinin faktör analizine uygun olup olmadığını belirlemek için Kaiser-Meyer-Olkin (KMO) testi ve Bartlett testinden yararlanılmıştır. KMO değerinin 0,815 ve Bartlett testinin anlamlı $(\mathrm{p}=0,00<0,05)$ olması nedeniyle veri setinin faktör analizi için oldukça uygun olduğu saptanmıştır. Açıklayıcı faktör analizinin uygulanmasının ardından, tek boyut oluşturduğu görülen "Okulumu diğer öğretmenlerin yanında eleştirmem" ifadesi ölçekten çıkarılmıştır. İfadenin çıkarılmasının ardından KMO değerinin arttığı, açıklanan toplam varyans oranının yükseldiği ve araştırmacılar tarafından kabul gören \%50'nin üzerine çıktığ 1 ve orijinal ölçeklere uygun olarak faktör özdeğeri 1'den büyük olan büyük olan üç faktör elde edildiği görülmüştür. Buradan hareketle, ifadenin ölçekten çıkarılmasının doğru olduğu söylenebilir. Tablo 3'te, üç boyut içerisinde yer alan ifadelerin faktör yüklerine yer verilmiştir.

Tablo 3. Açıklayıcı faktör yükleri

\begin{tabular}{cccc}
\hline İfade & & Faktör Bileşenleri & \\
\cline { 2 - 4 } No & $\begin{array}{c}\text { Faktör 1 } \\
\text { Kat1lımci İklim) }\end{array}$ & $\begin{array}{c}\text { Faktör 2 } \\
\text { (Dikey Muhalefet) }\end{array}$ & $\begin{array}{c}\text { Faktör 3 } \\
\text { (Yatay Muhalefet) }\end{array}$ \\
\hline KI4 &, 876 & & \\
Kİ3 &, 864 & & \\
Kİ2 &, 832 & & \\
Kİ1 &, 555 &, 750 & \\
DM7 & &, 701 & \\
DM4 & &, 617 & \\
DM3 & &, 600 & \\
DM1 & &, 598 &, 754 \\
DM2 & &, 569 &, 723 \\
DM8 & &, 559 &, 718 \\
DM5 & &, 532 &, 500 \\
DM6 & & &, 562 \\
YM3 & & & \\
YM4 & & & \\
YM7 & & & \\
YM5 & & & \\
YM1 & & & \\
YM2 & & & \\
\hline
\end{tabular}

Tablo 3 'te görüldüğü gibi; üç boyut altında yer alan tüm faktör yüklerinin $0,5^{\prime}$ ten büyük olması nedeniyle, uygulanan faktör analizinin boyutlar arasındaki korelasyonları doğru yansıttığ1 söylenebilir.

Araştırma kapsamında kullanılan ölçeklere ait güvenilirlik analizi sonuçları Tablo 4'te gösterilmiştir. Tablo 4'te görüldüğ̈̈ gibi; katılımcı iklim algısı ve örgütsel muhalefet ölçeklerinin 
ve tüm alt boyutlarının Cronbach Alfa $(\alpha)$ katsayıları 0,5'ten büyüktür. Bu doğrultuda, araştırmada kullanılan ölçeklerin güvenilir olduğu belirtilebilir.

Tablo 4. Faktör analizi öncesi ve sonrası güvenilirlik analizi sonuçları

\begin{tabular}{cccc}
\hline \multirow{2}{*}{ Değişkenler } & Boyutlar & \multicolumn{2}{c}{ Cronbach Alfa $(\alpha)$ Katsayıları } \\
\cline { 2 - 4 } & Kaktör Analizi & $\begin{array}{c}\text { Faktör Analizi } \\
\text { Öncesi }\end{array}$ & Sonrası \\
\hline Katılımcı İklim & Katılımcı İklim Algısı & 0,808 & 0,808 \\
\hline \multirow{2}{*}{ Örgütsel Muhalefet } & Örgütsel Muhalefet & 0,825 & 0,839 \\
\cline { 2 - 4 } & Dikey Muhalefet & 0,809 & 0,809 \\
\cline { 2 - 4 } & Yatay Muhalefet & 0,748 & 0,774 \\
\hline $\begin{array}{c}\text { Katılımcı İklim ve } \\
\text { Örgütsel Muhalefet }\end{array}$ & $\begin{array}{c}\text { Katılımc1 İklim Algıs1, } \\
\text { Dikey ve Yatay Muhalefet }\end{array}$ & 0,822 & 0,831 \\
\hline
\end{tabular}

Faktör analizinin uygulanmasının ve ifadelerin çıarılmasının ardından örgütsel muhalefet ölçeğinin güvenilirlik katsayısının yükseldiği görülmektedir.

\subsection{Modellerin Test Edilmesi}

Yapısal Eşitlik Modeli-I: Belirlenen ilk teorik modelde yatay ve dikey muhalefetin katılımcı iklim algısına olan etkisini ölçümlemek amaçlanmaktadır. Bu doğrultuda meydana getirilen yapısal eşitlik modeli Şekil 2'de gösterilmektedir.

\section{Şekil 2. Yapısal eşitlik modeli I}

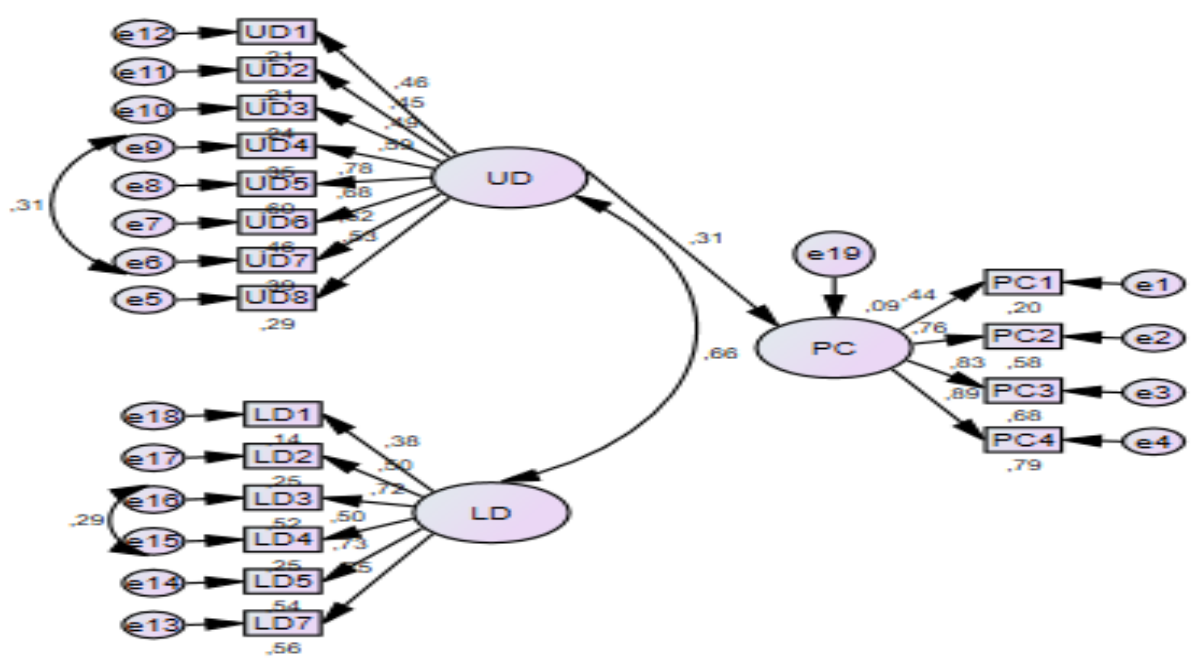

Modelde yer alan değişkenler arası yollardan; yatay muhalefetten katılımcı iklim algısına olan yol istatistiksel olarak anlamsız çıkmıştır. Dikey muhalefet ile katılımcı iklim algısı arasında nedensel ilişkinin olduğu belirlenmiştir. Modele ait model uyum iyiliği indeksleri $\chi 2 / \mathrm{df}=1,585$, $\mathrm{GFI}=0,875, \mathrm{CFI}=0,923$, RMSEA $=0,058$ şeklindedir. Modelin kabul edilebilir bir uyum içinde olduğu söylenebilir.

Tablo 5'te modele ilişkin standardize edilmemiş regresyon katsayıları, standardize edilmiş regresyon katsayıları, standart hatalar ve kritik oranlar görülmektedir.

Tablo 5. Model I'e ilişkin değerler

\begin{tabular}{|c|c|c|c|c|c|c|c|}
\hline & & & $\begin{array}{c}\text { Stand.Regression } \\
\text { Weight }(\beta)\end{array}$ & Estimate & S.E. & C.R. & $\mathrm{P}$ \\
\hline $\mathrm{KI}$ & $\leftarrow$ & DM & 0,307 & 0,335 & 0,117 & 2,865 & 0,004 \\
\hline
\end{tabular}


Analiz sonucuna göre yatay muhalefetin katılımcı iklim algısını etkilemediği sonucuna ulaşılmıştır. Yapısal eşitlik I modelinde dikey muhalefetten katılımcı iklim algısına çizilen yol doğrulanmış olup dikey muhalefetteki bir birimlik artış katılımcı iklim algısını 0,31 birim arttıracaktır.

Yapısal Eşitlik Modeli-II: İkinci teorik modelde katılımcı iklim algısının yatay ve dikey muhalefete olan etkisini ölçümlemek amaçlanmaktadır. Bu doğrultuda oluşturulan yapısal eşitlik modeli Şekil 3'te gösterilmektedir.

Şekil 3. Yapısal eşitlik modeli II

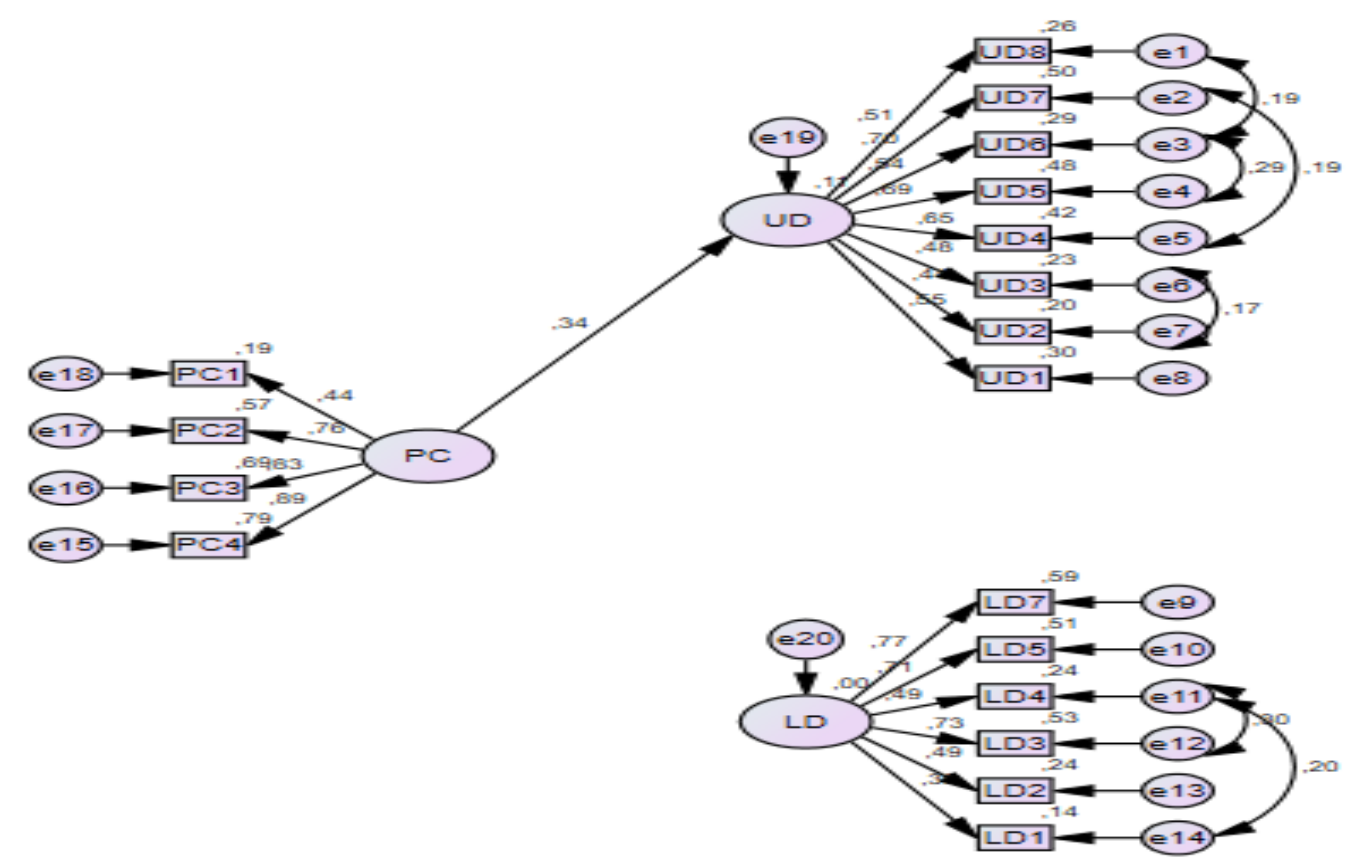

Modelde yer alan değişkenler arası yollardan; katılımcı iklim algısından yatay muhalefete olan yol istatistiksel olarak anlamsız çıkmıştır. Dikey muhalefet ile katılımcı iklim algısı arasında nedensel ilişkinin olduğu belirlenmiştir. Modele ait model uyum iyiliği indeksleri $\chi^{2} / \mathrm{df}=1,880$, $\mathrm{GFI}=0,870, \mathrm{CFI}=0,887, \mathrm{RMSEA}=0,072$ şeklindedir. Modelin kabul edilebilir bir uyum içinde olduğu belirtilebilir.

Tablo 6'da modele ilişkin standardize edilmemiş regresyon katsayıları, standardize edilmiş regresyon katsayıları, standart hatalar ve kritik oranlara yer verilmektedir.

Tablo 6. Model II’ye ilişkin değerler

\begin{tabular}{ccccccc}
\hline & & $\begin{array}{c}\text { Stand.Regression } \\
\text { Weight }(\beta)\end{array}$ & Estimate & S.E. & C.R. & P \\
\hline $\mathrm{DM} \leftarrow$ & KI & 0,338 & 0,168 & 0,05 & 3,33 & $* * *$ \\
\hline
\end{tabular}

Analiz sonucuna göre katılımcı iklim algısından yatay muhalefete çizilen yol anlamsız çıkmıştır. Yapısal eşitlik II modelinde katılımcı iklim algısından dikey muhalefete çizilen yol doğrulanmış olup katılımcı iklim algısındaki bir birimlik artış dikey muhalefeti 0,34 birim arttıracaktır.

Yapısal eşitlik modellerinin analizi sonucunda katılımcı iklim algısı ile yatay muhalefet arasında karşılıklı olarak hiçbir ilişkinin olmadığı belirlenmiştir. Bu doğrultuda $\mathrm{H} 2$ ve $\mathrm{H} 4$ hipotezleri reddedilmiştir. Analiz sonuçlarına göre katılımcı iklim algısı ile dikey muhalefet arasında ilişki olduğu görülmüş olup H1 ve H3 hipotezleri kabul edilmiştir. Her iki değişken arasındaki ilişkinin pozitif yönlü ancak zayıf düzeyde olduğu söylenebilir. 


\section{Sonuç ve Tartışma}

Çalışmada katılımcı iklim ile örgütsel muhalefet arasındaki ilişkiyi belirlemek amaçlanmıştır. Bu amaç doğrultusunda Tekirdağ merkez ilçedeki devlet ilköğretim okulları ve liselerinde görev yapan 188 öğretmen üzerinde bir araştırma yapılmıştır. Yürütülen araştırmanın sonuçlarına göre;

- Öğretmenlerin katılımcı iklim algılarının, dikey muhalefet davranışları üzerinde anlamlı bir etkisi olduğu tespit edilmiştir. Dolayısı ile katılımcı iklim algısının dikey muhalefeti daha çok geliştirdiği söylenebilir. Buna neden olarak, muhalif görüşlerin aktarılmasına olanak sağlayan bir ortamda çalışan öğretmenlerin iş arkadaşları yerine doğrudan yönetim ile iletişim kurabilmeleri gösterilebilir. Bu doğrultuda dikey muhalefetin tercih edilme nedeni olarak, iş doyumunu ve örgütsel bağlılığı arttırması gösterilebilir (Yıldız, 2013, s. 860).

- Dikey muhalefet davranışlarının katılımcı iklim algısını daha çok geliştirdiği belirlenmiştir. Çünkü muhalif görüşlerini ve eleştirel düşüncelerini yönetime aktarabilen öğretmenler, okul içerisinde katılımcı iklim ortamının var olduğunu hissedebilirler.

- Katılımcı iklim ile yatay muhalefet arasında herhangi bir ilişki olmadığı saptanmıştır. Öğretmenlerin iş arkadaşları ile muhalefet etmeleri örgüt içindeki katılımcı iklimi etkilememektedir.

Çalışmanın sonuçları, ilgili yazında ortaya koyulan katılımcı iklim algısı ile dikey örgütsel muhalefet davranışları arasındaki karşılıklı pozitif ilişkiyi dikey muhalefet açısından desteklemektedir. Özdemir (2013)'in yaptığı araştırmada öğretmenlerin muhalefet etmelerinin önemli bir nedeni olarak, kendilerini ilgilendiren konularda okul yöneticilerinin öğretmenlere danışmadan karar almaları gösterilmiştir. Ankara'daki beş lisede yapılan araştırmada öğretmenlerin en çok, kendilerine verilen görevlere muhalefet ettikleri ve karar alma sürecinin dışında tutulmaları durumunda muhalefet etme eğilimine girdikleri belirtilmektedir (Özdemir, 2011). Bu noktada yöneticilere düşen görev, muhalif davranışlar gösteren öğretmenlerin sorunlarına yapıcı bir yaklaşımla eğilmek ve aslında muhalefetin, eğitim-öğretim süreci ile örgüt içerisinde katılımı geliştirici bir yönünün bulunduğunun farkına varmaktır.

Benzer şekilde Iliman- Püsküllüoğlu ve Altınkurt (2018) Muğla ilinde görev yapan öğretmenler üzerinde yaptığı çalışmada öğretmenlerin en çok yöneticilerine daha sonra meslektaşlarına karşı muhalefet davranışında oldukları belirlenmiş olup çalışmada öğretmenlerin eleştirel düşünmelerinin yöneticilere yönelik uygulanan muhalefetin bir yordayıcısı olduğu sonucuna ulaşılmıştır. Eleştirel düşünebilme katılımcı bir iklimin olduğu çalışma ortamında ortaya çıkabileceğinden ilgili çalışmanın sonuçları ile araştırma sonuçlarının birbirini desteklediği söylenebilir.

İlgili yazında ayrıca muhalefet davranışı ile okul türü arasında bağlantı durumu araştırılmış ve Yıldız (2014) tarafından Bolu ili merkez ilçede yapılan çalışmada ilkokul öğretmenlerinin ortaokul öğretmenlerine göre daha çok meslektaşlarına muhalefet davranış1 uyguladığı sonucuna ulaşılmıştır.

İlgili yazında öğretmenler dışında başka sektörlerde çalışanlar üzerinde gerçekleştirilen araştırmalar da muhalefet davranışının genellikle dikey olarak gerçekleştiğini ve katılımcı bir ortamın muhalefeti arttırdığı ayrıca muhalefetin de örgütün refahı açısından gerekli olduğunu göstermektedir. Sadyakova ve Tutar (2014) ticaret borsası çalışanları üzerine yaptıkları araştırmada demokratik yönetimin ve demokratik davranışın üst düzey yöneticilere yapılan muhalefet davranışını olumlu yönde etkilediğini belirtmiştir. Oral Ataç ve Köse (2017), sanayi ve hizmet sektöründe çalışan beyaz yakalılar üzerine yaptıkları çalışmada örgütsel demokrasinin yöneticilere karşı yapılan dikey muhalefeti olumlu yönde etkilediği ayrıca yöneticilere karşı dile getirilen muhalefetin düzeyinin, aynı zamanda o örgütün demokratikleşme düzeyini gösteren bir işaret olduğu sonucuna ulaşmışlardır. De Dreu ve West (2001) çalışanların karar verme sürecine yüksek düzeyde katılım gösterdikleri zaman muhalefet davranışının ortaya çıkabileceğini 
belirtmişlerdir. Araştırmalar doğrultusunda örgütlerde katılımc1, herkesin düşüncesini ifade ettiği, eleştirel düşünmenin teşvik edildiği demokratik çalışma ortamlarının çalışanları muhalefet yapmaya yönlendirdiği, aynı zamanda muhalefetin olduğu örgütlerin demokratik ve katılımcı örgütler olduğu söylenebilir. Dikey muhalefetin, örgütün sağl1klı olduğunu işaret eden bir gösterge olduğu belirtilebilir.

\section{Öneriler}

Çalışmadan elde edilen sonuçlar ve ilgili alanda yapılan diğer araştırmalar çerçevesinde örgütlerde muhalefet davranışının desteklendiği bir ortamın gerekliliğinden söz edilebilir. Aynı zamanda çalışanlar tarafından muhalefet davranışı gösterilmesi örgüt yapısı hakkında fikir vermekte olup muhalefetin gerçekleştiği örgütlerin demokratik ve katılımc1 örgütler olduğu belirtilebilir. Bu doğrultuda örgüt yöneticilerine düşen görev muhalefet davranışının olumsuz yanlarının olmadığı, aksine örgütün gelişim ve değişimini desteklediği bilincine sahip olmaktır. Yöneticiler bu bilinç ile katılımcı davranışı teşvik ederek örgütsel muhalefetin gerçekleşmesine yardımcı olabilirler. Eğitim sektörü açısından ise okul yöneticilerinin öğretmenlerin görüşünü alarak karar vermeleri, öğretmenlere danışmaktan çekinmemeleri gerekmektedir. Öğretmenlerin düşüncelerini ifade edebildikleri, olayları ve durumları sorgulayabildikleri, önerilerde bulunabildikleri, okul yönetiminde aktif rol alabildikleri bir çalışma ortamı oluşturulmalıdır. Okul yöneticisinin çalışma ortamını bu şekilde düzenleyip iletişim kanallarını açık tutarak davranması halinde öğretmenlerin yaratıcı fikirlerinin gelişmesine dolayısıyla öğrencilerin de yaratıcı olmalarına katkı sağlanabilir. Eğitimin dinamik bir şekilde gerçekleşmesinin, sunulan eğitimin kalitesi, dolayısıyla da gelecek nesillerin daha bilinçli yetişmesi açısından önemli olduğu söylenebilir.

Araştırma kapsamında daha doğru sonuçların elde edilebilmesi ve araştırma sınırlılıklarının ortadan kaldırılabilmesi için gelecek araştırmalarda; ölçeğin uygulandığı evrenin genişletilmesi ve daha çok sayıda öğretmenin araştırmaya dahil edilmesi, örneklem büyüklüğünün tamamına ulaşılmaya çalışılması gerekmektedir. Ayrıca özel kurumlar ile kamu kurumları arasında karşılaştırma yapılarak kurum sahipliğinin ve okul türünün değişkenleri nasıl etkilediği ortaya koyulabilir. Bunun yanı sıra, araştırma kapsamında ele alınan değişkenlerin başka değişkenler ile olan ilişkisi farklı sektörlerde incelenerek söz konusu kavramların diğer yönleri de ele alınabilir. Böylece, araştırma kapsamındaki değişkenler arasındaki ilişkide etkide bulunan ve analiz sonucunda elde edilen oranların düşük kalmasına neden olan diğer unsurlar ortaya çıkarılabilir.

\section{Kaynakça}

Acaray, A. (2018). Örgütsel muhalefet üzerine pozitif psikolojik sermayenin etkisi: Eğitim sektöründe bir çalışma. Anemon Muş Alparslan Üniversitesi Sosyal Bilimler Dergisi, 6, 8391.

Akada, T. ve Beycioğlu, K. (2017). Ortaokul öğretmenlerinin örgütsel muhalefet davranışlarına ilişkin görüşleri: İzmir ili Buca merkez ilçesi örneği. 5. Uluslararası Öğretim Teknolojileri ve Öğretmen Ĕ̈itimi Sempozyumu, 11-13 Ekim 2017, İzmir, Türkiye.

Angermeier, I., Dunford, B. B., Boss, A. D. \& Boss, R. W. (2009). The impact of participative management perceptions on customer service, medical errors, burnout and turnover intentions. Journal of Healthcare Management, 54(2), 127-141.

Ataç Oral, L. ve Köse, S. (2017). Örgütsel demokrasi ve örgütsel muhalefet ilişkisi: Beyaz yakalılar üzerine bir araştırma. İstanbul Üniversitesi Işsletme Fakültesi Dergisi, 46(1), 117 132.

Avtgis, A. T., Candice, T. M., Elycia, T. \& Patterson, B. R. (2007). The influence of employee burnout syndrome on the expression of organizational dissent. Communication Research Methods, 24(2), 97-102. 
Bakan, İ., Doğan, F. İ. ve Yılmaz, S. Y. (2017). Çalışanlarda mesleki öz yeterlilik algısı ile örgütsel muhalefet ilişkisi. Organizasyon ve Yönetim Bilimleri Dergisi, 9(2), 54-70.

Bal, T. S. (2013). The influences of participative organizational climate and self-leadership on innovative behavior and the roles of job involvement and proactive personality: A survey in the context of SMEs in İzmir. Social and Behavioral Sciences, 75, 407-419.

Bartkus, R. B. (1997). Employee ownership as catalyst of organizational change. Journal of Organizational Change Management, 10(4), 331-344.

Bayram, N. (2010). Yapısal Eşitlik Modellemesine giriş: AMOS uygulamaları. Bursa: Ezgi Kitapevi.

Bordin, C., Bartram, T. \& Casimir, G. (2007). The antecedents and consequences of psychological empowerment among Singaporean IT employees. Management Research News, 30(1), 34-46.

Brown, M. \& Cregan, C. (2008). Organizational change cynicism: The role of employee involvement. Human Resource Management, 47(4), 667-686.

Bryne, B. M. (2010). Structural Equation Modeling with AMOS: Basic concepts, applications and programming. 2nd Edition, USA: Taylor \& Francis Group.

Cohen, L., Manion, L. \& Morrison, K. (2007). Research methods in education. 6th Edition, New York: Routledge.

Croucher, M. Stephen, Braziunaite, R., Homsey, D., Pillai, G., Saxena, J., Saldanha, A., Joshi, V.,Jafri, I., Choudhary, P., Bose, L. \& Agarwal, K. (2009). Organizational dissent and argumentativeness: A comparative analysis between American Indian organizations. Journal of Intercultural Communication Research, 38(3), 175-191.

Croucher, M. S., Zeng, C., Rahmani, D. \& Cui, X. (2017). The relationship between organizational dissent and workplace freedom of speech: A cross-cultural analysis in Singapore. Journal of Management \& Organization, 24(6), 793-807.

Çokluk, Ö., Şekercioğlu, G. ve Büyüköztürk, Ş. (2012). Sosyal bilimler için çok değiş̧kenli istatistik SPSS ve Lisrel uygulamaları. 2. Bask1, Ankara: Pegem Akademi.

Dağl1, A. (2015). Örgütsel muhalefet ölçeğinin Türkçe’ye uyarlanması: Geçerlik ve güvenirlik çalışması. Elektronik Sosyal Bilimler Dergisi, 14(53), 198-218.

Dağl1, A. ve Ağalday, B. (2015). Öğretmenlerin örgütsel muhalefetin nedenlerine ilişkin görüşleri. İlköğretim Online, 14(3), 885-898.

De Dreu, C. K. W. \& West, M. A. (2001). Minority dissent and team innovation: The importance of participation of decision making. Journal of Applied Psychology, 86(6), 1191-1201.

Demiralay, T. (2014). Hekimlerde örgütsel sessizliğin Yapısal Eşitlik Modeli ile incelenmesi. Trakya Üniversitesi Sosyal Bilimler Enstitüsü, Doktora Tezi, Edirne.

Garner, T. J. (2011). Making waves at work: Perceived effectiveness and appropriateness of organizational dissent messages. Management Communication Quarterly, XX(X), 1-17.

Garner, T. J. (2013). Dissenters, managers and coworkers: The process of co-constructing organizational dissent and dissent effectiveness. Management Communication Quarterly, $X X(\mathrm{X}), 1-23$.

Goodboy, K. A., Chory, M. R. \& Dunleavy, K. N. (2008). Organizational dissent as a function of organizational justice. Communication Research Reports, 25(4), 255-265.

Huang, X., Van de Vliert, E. \& Van der Vegt, G. (2005). Breaking the silence culture: Stimulation of participation and employee opinion withholding cross-nationally. Management and Organization Review, 1(3), 459-482. 
http://www.meb.gov.tr/baglantilar/okullar/index.php?ILKODU=59\&ILCEKODU=1， (Erişim tarihi: 01.03.2016).

http://tdk.gov.tr/index.php?option=com_gts\&arama=gts\&guid=TDK.GTS.56e04814081ff2.990 92510, (Erişim tarihi: 09.02.2019).

http://www.oxforddictionaries.com/definition/english/dissent, (Erişim tarihi: 09.02.2019).

Iliman Püsküllüoğlu, E. ve Altınkurt, Y. (2018). Öğretmenlerin eleştirel düşünme eğilimleri ile örgütsel muhalefet davranışları arasındaki ilişki. Hacettepe Üniversitesi Ĕgitim Fakültesi Dergisi, 33(4), 897-914.

Jadon, S. P. \& Upadhyay, K. B. (2018). Employee retention in public and private hospital settings: An empirical study of its relationship with participative climate, and role performance. Indian Journal of Commerce \& Management Studies, 9(1), 37-46.

Kadı, A. ve Beytekin, F. O. (2015). Okul kültürü ve örgütsel muhalefet davranışları arasındaki ilişskinin meslekî değerler aracılığıyla araştırılması. Kalem Eğitim ve İnsan Bilimleri Dergisi, 5(1), 71-97.

Kassing, W. J. (1997). Articulating, antagonizing and displacing: A model of employee dissent. Communication Studies, 48(4), 311-332.

Kassing, W. J. (1998). Development and validation of the organizational dissent scale. Management Communication Quarterly, 12(2), 183-229.

Kassing, W. J. \& Avtgis, A. T. (1999). Examining the relationship between organizational dissent and aggressive communication. Management Communication Quarterly, 13(1), 100-115.

Kassing, W. J. (2000a). Exploring the relationship between workplace freedom of speech, organizational identification and employee dissent. Communication Research Reports, 17(4), 387-396.

Kassing, W. J. (2000b). Investigating the relationship between superior-subordinate relationship quality and employee dissent. Communication Research Reports, 17(1), 58-69.

Kline, R. B. (2011). Principles and practice of Structural Equation Modelling. 3rd Edition, USA: Guilford Press.

Korucuoğlu, T. ve Şentürk, İ. (2018). Örgütsel güç oyunları ve örgütsel muhalefet arasındaki ilişki. Hacettepe Üniversitesi Eğitim Fakültesi Dergisi, Advance online publication. doi: 10.16986/HUJE.2018045306.

Lee, L. G., Diefendorff, M. J, Tae-Yeol, K. \& Lin, B. (2014). Personality and participative climate: Antecedents of distinct voice behaviors. Human Performance, 27(1), 25-43.

Liverpool, R. P. (1990). Employee participation in decision-making: An analysis of the perceptions of members and nonmembers of quality circles. Journal of Business and Psychology, 4(4), 411-422.

Mardia, K. V. (1970). Measures of multivariate skewness and kurtosis with applications. Biometrika, 57(3), 519-530.

Mehta, A. (2009). Organisation development: Principles, process and performance. New Delhi: Global India Publications.

Miller, I. K. \& Monge, R. P. (1986). Participation, satisfaction and productivity: A meta-analytic review. The Academy of Management Journal, 29(4), 727-753.

Oral-Ataç, L. ve Köse, S. (2017). Örgütsel demokrasi ve örgütsel muhalefet ilişkisi: Beyaz yakalılar üzerine bir araştırma. İstanbul Üniversitesi İşletme Fakültesi Dergisi, 46(1), 117 132. 
Ötken, B. A. ve Cenkci, T. (2013). Beş faktör kişilik modeli ve örgütsel muhalefet arasındaki ilişki üzerine bir araştırma. Öneri Dergisi, 10(39), 41-51.

Özdemir, M. (2011). Lise yöneticilerinin öğretmenlerin örgütsel muhalefet davranışlarına ilişkin görüşleri. Kuram ve Uygulamada Eğitim Bilimleri, 11(4), 1895-1908.

Özdemir, M. (2013). Genel liselerde görev yapan öğretmenlerin örgütsel muhalefete ilişkin görüşleri (Ankara ili örneği). Eğitim ve Bilim, 38(168), 113-128.

Sadykova, G. ve Tutar, H. (2014). Örgütsel demokrasi ile örgütsel muhalefet arasındaki ilişki üzerine bir inceleme. İşletme Bilimi Dergisi, 2(1), 1-16.

Short, M. P. \& Rinehart, S. J. (1992). Teacher empowerment and school climate. Annual Meeting of the American Educational Research Association, San Francisco.

Smits, A. P. \& Champagne, F. (2008). An assessment of the theoretical underpinnings of practical participatory evaluation. American Journal of Evaluation, 29(4), 427-442.

Taylor, L. D. \& Tashakkori, A. (1994). Predicting teachers' sense of efficacy and job satisfaction using school climate and participatory decision making. Annual Meeting of the Southwest Educational Research Association, San Antonio.

Tesluk, E. P., Vance, J. R. \& Mathieu, E. J. (1999). Examining employee involvement in the context of participative work environments. Group\&Organization Management, 24(3), 271299.

Turnage, K. A. \& Goodboy, K. A. (2014). E-Mail and face-to-face organizational dissent as a function of leader-member exchange status. International Journal of Business Communication, 1-15.

Turnbull, B. (1999). The mediating effect of participation efficacy on evaluation use. Evaluation and Program Planning, 22, 131-140.

Uğurlu, E. ve Bostanc1, B. A. (2017). Öğretmenlerin politik yetileri ile örgütsel muhalefet düzeyleri arasındaki ilişki. International Journal of Human Sciences, 14(4), 4050-4064.

Yıldız, K. (2013). Örgütsel bağl1lık ile örgütsel sinizm ve örgütsel muhalefet arasındaki ilişki, International Periodical for the Languages, Literature and History of Turkish and Turkic, 8(6), 853-879.

Yıldız, K. (2014). “Örgütsel muhalefet”, Akademik Bakış Dergisi, 43.

ETIKK ve BİLIMSEL İLKELER SORUMLULUK BEYANI

$\mathrm{Bu}$ çalışmanın tüm hazırlanma süreçlerinde etik kurallara ve bilimsel atıf gösterme ilkelerine riayet edildiğini yazar(lar) beyan eder. Aksi bir durumun tespiti halinde Afyon Kocatepe Üniversitesi Sosyal Bilimler Dergisi'nin hiçbir sorumluluğu olmayıp, tüm sorumluluk makale yazarlarına aittir 